\title{
Forage cactus-sorghum intercropping at different irrigation water depths in the Brazilian Semiarid Region
}

\author{
Wellington Jairo da Silva Diniz ${ }^{(1)}$, Thieres George Freire da Silva(1), Jadna Mylena da Silva Ferreira ${ }^{(1)}$, \\ Djalma Cordeiro dos Santos ${ }^{(2)}$, Magna Soelma Beserra de Moura ${ }^{(3)}$, \\ Gherman Garcia Leal de Araújo ${ }^{(3)}$ and Sérgio Zolnier(4)
}

\begin{abstract}
(1)Universidade Federal Rural de Pernambuco, Unidade Acadêmica de Serra Talhada, Caixa Postal 063, CEP 56900-000 Serra Talhada, PE, Brazil. E-mail: wellingtonjairo@hotmail.com, thieres_freire@yahoo.com.br, jadna.mylena@hotmail.com (2)Instituto Agronômico de Pernambuco, BR-232, Km 253, CEP 56500-000 Arcoverde, PE, Brazil. E-mail: djalma.cordeiro@ipa.br (3)Embrapa Semiárido, BR-428, Km 152, Zona Rural, Caixa Postal 23, CEP 56302-970 Petrolina, PE, Brazil. E-mail: magna.moura@embrapa.br, gherman.araujo@embrapa.br (4)Universidade Federal de Viçosa, Avenida P.H. Rolfs, s/non, CEP 36570-900 Viçosa, MG, Brazil. E-mail: zolnier@ufv.br
\end{abstract}

\begin{abstract}
The objective of this work was to evaluate the productive performance, biological efficiency, and the competitive ability of the forage cactus-sorghum intercropping under different irrigation depths with saline water in the Brazilian Semiarid Region. The experiment was carried out in Serra Talhada, in the state of Pernambuco, between 2014 and 2015, in a randomized complete block design, with four replicates, and a 5x3 factorial arrangement in split plots, with one year of forage cactus cycle and two years of sorghum cycles. The plots were composed by four irrigation water depths based on the fractions of $25,50,75$, and $100 \%$ of the reference evapotranspiration, besides dry conditions; and the subplots consisted of three cropping systems (single crop of forage cactus, single crop of sorghum, and intercropping of forage cactus-sorghum). The increase of water irrigation depths increased the yields of sorghum in single crop and of the forage cactus-sorghum intercropping. The intercropping system promoted production stability with a higher system productivity index (SPI) for forage cactus-sorghum intercropping $(6,279.02$ $\left.\mathrm{kg} \mathrm{ha}^{-1} \mathrm{DM}\right)$ than for forage cactus in single crop $\left(4,626.98 \mathrm{~kg} \mathrm{ha}^{-1} \mathrm{DM}\right)$. The relative density coefficient (12.33) was indicative of the great compatibility of the intercropping system. The forage cactus-sorghum association shows biological advantage and competitiveness capacity, with a higher productive index than their monocultures.
\end{abstract}

Index terms: Opuntia stricta, Sorghum bicolor, agronomic performance, biological efficiency, competitive ability, saline water irrigation.

\section{Consórcio palma-sorgo irrigado com diferentes lâminas de água no Semiárido brasileiro}

Resumo - $\mathrm{O}$ objetivo deste trabalho foi avaliar o desempenho produtivo, a eficiência biológica e a habilidade competitiva do consórcio palma-sorgo sob irrigação com diferentes lâminas de água salina, no Semiárido brasileiro. O experimento foi realizado em Serra Talhada, PE, entre 2014 e 2015, em delineamento de blocos ao acaso, com quatro repetições, em arranjo fatorial $5 \times 3$, com parcelas subdivididas, tendo sido um ano de ciclo de palma e dois ciclos de sorgo. As parcelas foram compostas por quatro lâminas de irrigação com base nas frações de 25,50 , 75 e $100 \%$ da evapotranspiração de referência, além das condições de sequeiro, e as subparcelas consistiram de três sistemas de plantio (palma solteira, sorgo solteiro e consórcio palma-sorgo). $\mathrm{O}$ aumento das lâminas de água incrementou a produtividade do sorgo e do consórcio palma-sorgo. O consórcio promoveu estabilidade na produção, com índice de produtividade do sistema (IPS) palma-sorgo $\left(6.279,02 \mathrm{~kg} \mathrm{ha}^{-1} \mathrm{MS}\right)$ maior que o de palma em cultivo solteiro $\left(4.626,98 \mathrm{~kg} \mathrm{ha}^{-1} \mathrm{MS}\right)$. O coeficiente de adensamento relativo $(12,33)$ foi indicativo de ótima compatibilidade do consórcio. A associação palma-sorgo apresenta vantagem biológica e capacidade competitiva com maior índice produtivo que os dos seus monocultivos.

Termos para indexação: Opuntia stricta, Sorghum bicolor, desempenho agronômico, eficiência biológica, habilidade competitiva, irrigação com água salina.

\section{Introduction}

The Brazilian Semiarid Region shows seasonal rainfalls that impacts the production of forage and causes losses to farmers. Associated to this fact, the low technology level lead to the livestock raising in the extensive production system, in which native vegetation with low forage mass is the basis of animal feeding (Oliveira et al., 2010). 
In this context, irrigation plays a fundamental role in the regional development, as it allows a greater production and reduces economic losses. However, most of the time, its use in the semiarid environment is associated with saline water; therefore, it is important to know its effects on the agronomic performance of crops. Forage cactus [Opuntia stricta (Haw.) Haw.)] and sorghum [Sorghum bicolor (L.) Moench)] are highly efficient as to water use due to their crassulacean acid metabolism (CAM) and $\mathrm{C} 4$ physiological mechanisms. Both crops are widely used for animal feed in the Brazilian Semiarid Region because of their good acceptability and easy digestibility by the animals, besides being a source of energy and carbohydrates. In addition, the cladodes of forage cactus show a great reserve of water which can serve to quench the animals thirst during the dry season. However, when supplied as the sole food source, it can cause diarrhea because of its low contents of fiber. Therefore, the inclusion of sorghum in the diet may supply this deficiency (Galvão Júnior et al., 2014). Freire (2012) reported on the sensitivity of some forage cactus cultivars to the salinity of water. Under this condition, the use of seasonal irrigation is recommended to reduce impacts on production. Studies on several agricultural species under saline water irrigation are known (Silva et al., 2014; Kiremit \& Arslan, 2016); however, no report was found in the literature on the use of this condition in semiarid-adapted forage crops, mainly in different planting systems. Intercropping is extremely important for the sustainable management of local livestock. It is a commonly applied practice for food crops in the Brazilian Semiarid Region, and it is employed by farmers to improve the efficiency of agronomic attributes by intensifying land use with the cultivation of more than one species in the same area and at the same time (Costa et al., 2010; Souza et al., 2011). However, the use of intercropping should be followed by an agronomic, ecological, and socioeconomic evaluation, in order to understand its effects on the agricultural system (Silva et al., 2013). In this type of evaluation, crop co-participation is considered for the risk reduction of losses due to adverse conditions (droughts, high temperatures, pests, and diseases), and for the increase of production and economic return for the success of the activity (Atis et al., 2012; Yilmaz et al., 2015).
Intercropping can be evaluated by the biological efficiency indices - as land use efficiency (LUE), area-time equivalent ratio (ATER), land equivalent coefficient (LEC), and system productivity index (SPI) -, as well as by the competitive ability of the crops (RAC) - as relative density coefficient (RDC), competitiveness ratio (CR), aggressiveness (A), and loss or actual yield gain (LAYG), which allow to subsidize decision making (Sadeghpour et al., 2013; Silva et al., 2013).

Farias et al. (2000) evaluated forage cactus-sorghum intercropping at different planting spacings under dry conditions, and verified a productive increase of the planting system, depending on the adopted population density.

Although forage cactus-sorghum intercropping and the use of irrigation with saline water may reduce the yield of the two crops, the association of these crops raises the possibility of increasing the total production, as mentioned for other irrigated intercropping systems (Miriti et al., 2012; Thierfelder et al., 2012; Wang et al., 2015). The evaluation of intercropping for the use of biological efficiency indices and competitive ability makes it possible to subsidize the public policies, in order to provide socioeconomic improvements.

The objective of this work was to evaluate the productive performance, biological efficiency, and the competitive ability of the forage cactus-sorghum intercropping under different irrigation depths with saline water in the Brazilian Semiarid Region.

\section{Materials and Methods}

The experiment was conducted at the Estação Experimental Lauro Ramos Bezerra ( $7^{\circ} 59^{\prime} \mathrm{S}, 38^{\circ} 15^{\prime} \mathrm{W}$, at $431 \mathrm{~m}$ altitude) of Instituto Agronômico de Pernambuco (IPA), in Serra Talhada, PE, Brazil, in the Brazilian Semiarid Region, from November 2014 to November 2015, during a productive year of the forage cactus and two cycles of forage sorghum. The soil of the experimental area was classified as an Argissolo Vermelho-Amarelo eutrófico franco arenoso, i.e., an Ultisol, according to Embrapa (Santos et al., 2013). Over the duration of the experiment, the average air temperature was $26.5^{\circ} \mathrm{C}$, and rainfall and reference evapotranspiration (ETo) were 354.7 and 2,072 $\mathrm{mm}$, respectively (Table 1). Air temperature was above the 
historical average $\left(25.9^{\circ} \mathrm{C}\right)$, and rainfall (657) and ETo $(2,232 \mathrm{~mm})$ were lower.

The forage cactus cultivar Orelha de Elefante Mexicana and the sorghum cultivar SF-15 were distributed in a randomized complete block design with four replicates, in a $5 \times 3$ factorial arrangement in split plots. The plots were composed of four water irrigation depths based on fractions of $25,50,75$, and $100 \%$ of the ETo, and a control in dry conditions. The subplots consisted of three planting systems (forage cactus in single crop, forage sorghum in a single crop, and cactus-sorghum intercropping system). The irrigation water depths totaled 208.3, 369.7, 511.8, and $656.5 \mathrm{~mm}$ per year (Table 1) which added to rainfall resulted in 354.7 (dry), 563.0, 724.4, 867.5, and 1,012.2 $\mathrm{mm}$ per year. Irrigation events were made with saline water (electrical conductivity between 1.6 and 2.5 $\mathrm{dS} \mathrm{m}^{-1}$ ) from the Açude Saco only when accumulated ETo reached $75 \%$ of the rainfall, and the remainder was considered as unaccounted water loss. After rainfalls, the irrigation water depths were calculated from the accumulated ETo of the last two days.

The irrigation system used was drip irrigation, with tapes positioned next to the cultivation rows in the single croppings, and drippings were spaced at $0.4 \mathrm{~m}$, with $1.35 \mathrm{~L} \mathrm{~h}^{-1}$ flow rate at 1 atm and 93\% distribution coefficient. In the intercropping system, the drip tape was placed between the rows of forage cactus and sorghum.

The single forage cactus system was set at $1.6 \times 0.4 \mathrm{~m}$ spacing, with a density of 15,625 plants $h^{-1}$, while single sorghum was set in rows spaced at $1.6 \mathrm{~m}$, which resulted in a density of 170,000 plants ha ${ }^{-1}$. The forage cactus-sorghum intercropping was composed of $8 \%$ of forage cactus plants $\left(15,625\right.$ plants ha $\left.{ }^{-1}\right)$, spaced at $1.6 \times 0.4 \mathrm{~m}$, and $92 \%$ of forage sorghum plants $(170,000$ plants ha $\mathrm{h}^{-1}$ ) in a single row, at $0.2 \mathrm{~m}$ from the cactus. The subplots were composed of four rows of $6 \mathrm{~m}$ each, with the two central rows being the useful area, and the outer ones, the borders.

Sorghum was sown on January 8, 2015, approximately two months after the beginning of the forage cactus cycle, to ensure the initial sprouting of the cladodes. Sorghum thinning was performed 20 days after planting, and weeding was performed whenever necessary. During the experimental period, two chemical fertilizations with NPK were carried out at the formulation 14-00-18 $+16 \mathrm{~S}$, and $525 \mathrm{~kg} \mathrm{ha}^{-1}$ were applied $\left(73.5 \mathrm{~kg} \mathrm{~N} \mathrm{ha}^{-1}, 94.5 \mathrm{~kg} \mathrm{~K}_{2} \mathrm{O} \mathrm{ha}{ }^{-1}\right.$ and 84 $\operatorname{kg~S~ha-1).~}$

The weather variables global solar radiation, $\mathrm{MJ} \mathrm{m}^{-2}$ per day; air temperature, ${ }^{\circ} \mathrm{C}$; relative air humidity, $\%$; atmospheric pressure, $\mathrm{hPa}$; and wind speed, $\mathrm{m} \mathrm{s}^{-1}$; were monitored during the experimental period at the

Table 1. Number of days per month, average air temperature ( $\mathrm{t}_{\mathrm{a}}$ ), rainfall, reference evapotranspiration (ETo), and monthly irrigation water depths applied in treatments based on fractions of 25, 50, 75, and 100\% of ETo, in Serra Talhada, PE, Brazil - Brazilian Semiarid Region.

\begin{tabular}{|c|c|c|c|c|c|c|c|c|}
\hline \multirow[t]{2}{*}{ Month and year } & \multirow{2}{*}{$\begin{array}{l}\text { Number } \\
\text { of days }\end{array}$} & \multirow{2}{*}{$\begin{array}{c}\mathrm{T}_{\mathrm{a}} \\
\left({ }^{\circ} \mathrm{C}\right)\end{array}$} & \multirow{2}{*}{$\begin{array}{c}\text { Rainfall } \\
(\mathrm{mm})\end{array}$} & \multirow{2}{*}{$\begin{array}{l}\text { ETo } \\
(\mathrm{mm})\end{array}$} & \multicolumn{4}{|c|}{ Irrigation water depths (mm) } \\
\hline & & & & & $25 \%$ & $50 \%$ & $75 \%$ & $100 \%$ \\
\hline November 2014 & 15 & 27.2 & 91.1 & 172 & 0.0 & 0.0 & 0.0 & 0.0 \\
\hline December 2014 & 31 & 26.8 & 11.4 & 171 & 0.0 & 0.0 & 0.0 & 0.0 \\
\hline January 2015 & 31 & 27.2 & 45.0 & 177 & 15.0 & 26.6 & 36.9 & 47.4 \\
\hline February 2015 & 28 & 27.1 & 63.6 & 150 & 14.3 & 25.5 & 35.4 & 45.4 \\
\hline March 2015 & 31 & 26.6 & 67.0 & 156 & 10.6 & 19.2 & 26.8 & 34.8 \\
\hline April 2015 & 30 & 26.6 & 20.6 & 146 & 25.5 & 45.3 & 62.9 & 80.7 \\
\hline May 2015 & 31 & 26.5 & 5.6 & 139 & 23.9 & 42.5 & 59.1 & 76.0 \\
\hline June 2015 & 30 & 24.3 & 47.6 & 110 & 18.7 & 33.1 & 46.0 & 59.0 \\
\hline July 2015 & 31 & 23.5 & 2.8 & 116 & 15.2 & 26.9 & 37.3 & 47.9 \\
\hline August 2015 & 31 & 24.5 & 0.0 & 157 & 27.4 & 48.5 & 67.4 & 86.5 \\
\hline September 2015 & 30 & 27.0 & 0.0 & 178 & 31.4 & 55.6 & 75.4 & 95.6 \\
\hline October 2015 & 31 & 27.8 & 0.0 & 199 & 20.1 & 35.6 & 49.4 & 63.5 \\
\hline November 2015 & 9 & 29.1 & 0.0 & 201 & 6.2 & 11.1 & 15.3 & 19.7 \\
\hline Sum & 421 & $26.5^{(1)}$ & 354.7 & 2,072 & 208.3 & 369.7 & 511.8 & 656.5 \\
\hline
\end{tabular}

${ }^{(1)}$ Mean. 
automatic meteorological station of Instituto Nacional de Meteorologia (Inmet), located $1.5 \mathrm{~km}$ away from the experimental area, for the ETo daily calculation by the Penman-Monteith method parameterized in the FAO Bulletin 56 (Allen et al., 1998). Rainfall data were recorded by an automatic rain gauge installed in the experimental area.

At harvesting of the first sorghum cycle (May 28, 2015), which occurred 147 days after sowing, and at the second cycle (regrowth evaluation), at 102 days after the first cut (September 9, 2015), ten plants of each subplot were cut at $0.10 \mathrm{~m}$ above the soil surface and weighed to obtain the fresh matter mass. Subsequently, each plant was separated into leaf, stem, and panicle fractions. After obtaining the fresh matter mass, three plants of each subplot were packed in paper bags and placed to dry, at $65^{\circ} \mathrm{C}$, in a forced-air circulation oven until reaching a constant mass. The sorghum total yield resulted from the extrapolation of the individual fresh and dry mass of the plants and the final density of plants.

After one year of the productive cycle, the forage cactus was harvested (November 9, 2015), to obtain the fresh matter mass of the plants of the useful area of each experimental plot, among which three cladodes were selected and fractionated. Later on, this material was dried for dry matter content (DMC) determination. Yield extrapolation on the fresh base (FM) was obtained from the plant mass of the useful plot, and on a dry basis (DM) by the product of FM and DMC.

The productive performance of the forage cactussorghum system was obtained by summing the forage sorghum yield of the two cycles with that of the forage cactus. Data of DM were used to evaluate the biological efficiency and the competitive ability of the intercropping.

The biological efficiency of the forage cactussorghum intercropping was obtained using indices of land efficiency use (LUE), area-time equivalent ratio (ATER), land equivalent ratio (LER), land equivalent coefficient (LEC) and system productivity index (SPI).

Land efficiency use expresses the area needed in a single crop to equal the same yield produced in the intercropping, measured in hectares: LER $=\mathrm{LER}_{\mathrm{a}}+\mathrm{LER}_{\mathrm{b}}$ or LER $=\left(\mathrm{Y}_{\mathrm{ab}} / \mathrm{Y}_{\mathrm{aa}}\right)+\left(\mathrm{Y}_{\mathrm{ba}} / \mathrm{Y}_{\mathrm{bb}}\right)$, in which: $Y_{a b}$ and $Y_{b a}$ represent the productivity of the crops $-\mathrm{a}$ (forage cactus), and $\mathrm{b}$ (sorghum) in the intercropping system; and $\mathrm{Y}_{\mathrm{a} a}$ and $\mathrm{Y}_{\mathrm{bb}}$ are the yields of each one in the single system. The first term of the equation represents the partial efficient use of the land with forage cactus $\left(\mathrm{LER}_{\mathrm{a}}\right)$, and the second, the partial efficient use of the land with sorghum $\left(\mathrm{LER}_{\mathrm{b}}\right)$. If LER $>1$, then a productive advantage of the intercropping system occurs; if $\mathrm{LER}=1$, no productive advantage occurs; and if LER $<1$, then a productive disadvantage of the intercropping system occurs.

The ATER was calculated because LER does not include the time factor, which may overestimate the advantage of the intercropping, especially when the crops of the intercropping system show a large difference in the productive cycle: ATER $=\left[\left(\operatorname{LER}_{a} \times t_{a}\right)+\left(\operatorname{LER}_{b} \times t_{b}\right)\right] / t_{a b}$, in which: $t_{a}$ is the length of the forage cactus cycle (365 days); $t_{b}$ is the length of the sorghum cycle (245 days); and $t_{a b}$ represents the total time of the intercropping system. If ATER $>1$, productive advantage occurs; if ATER $=1$, no productive advantage occurs; and if ATER $<1$, a productive disadvantage occurs.

LEC was calculated using the following equation $\mathrm{LEC}=\mathrm{LER}_{\mathrm{a}} \times \mathrm{LER}_{\mathrm{b}}$, in which: LEC should be at least $25 \%$ for the intercropping to show a productive advantage.

System productivity index (SPI) was achieved with the equation $\mathrm{SPI}=\left[\left(\mathrm{Y}_{\mathrm{aa}} / \mathrm{Y}_{\mathrm{bb}}\right) \times \mathrm{Y}_{\mathrm{ba}}\right]+\mathrm{Y}_{\mathrm{ab}}$.

The main advantage of SPI is that this index standardizes the yield of the secondary crop (sorghum) in relation to the main crop (forage cactus) (Oseni \& Aliyu, 2010).

In the evaluation of the competitive ability of the forage cactus-sorghum intercropping, the coefficient of relative density (K), aggressiveness (A), loss or actual gain of yield (LAGY) and competitiveness ratio (CR) were calculated.

In an intercropping system, $\mathrm{K}$ is a measure of the dominance relationship of one culture over another, according to the following equation: $\mathrm{K}=\mathrm{K}_{\mathrm{ab}} \times \mathrm{K}_{\mathrm{ba}}$ or $\mathrm{K}=\left\{\left(\mathrm{Y}_{\mathrm{ab}} \times \mathrm{Z}_{\mathrm{ba}}\right) /\left[\left(\mathrm{Y}_{\mathrm{aa}}-\mathrm{Y}_{\mathrm{ab}} \times \mathrm{Z}_{\mathrm{ab}}\right)\right]\right\} \times\left\{\left(\mathrm{Y}_{\mathrm{ba}} \times \mathrm{Z}_{\mathrm{ab}}\right)\right.$ $\left./\left[\left(Y_{b b}-Y_{b a}\right) \times Z_{b a}\right]\right\}$, in which: $Z_{a b}$ represents the planting proportion of species a (forage cactus, $8 \%$ ) intercropped with species $b$ (sorghum); $Z_{\text {ba }}$ represents the planting proportion of species $b$ (sorghum, 92\%) intercropped with species a (forage cactus). If $\mathrm{K}>1$, then a productive advantage of the intercropping system in relation to the single crop occurs; if $\mathrm{K}=1$, no productive advantage occurs; and if $K<1$, then a 
productive disadvantage of the intercropping system in relation to the single crop occurs. The coefficients of relative densities of $\mathrm{K}_{\mathrm{ab}}>\mathrm{K}_{\mathrm{ba}}$ are indicative that the main crop shows a strong interspecific competition.

The index A expresses the change of productivity of the two crops, as follows: $A_{a b}=\left[Y_{a b} /\left(Y_{a a} \times Z_{a b}\right)\right]-\left[Y_{b a}\right.$ $\left./\left(\mathrm{Y}_{\mathrm{ba}} \times \mathrm{Z}_{\mathrm{ba}}\right)\right]$ and $\mathrm{A}_{\mathrm{ba}}=\left[\mathrm{Y}_{\mathrm{ba}} /\left(\mathrm{Y}_{\mathrm{bb}} \times \mathrm{Z}_{\mathrm{ba}}\right)\right]-\left[\mathrm{Y}_{\mathrm{ab}} /\left(\mathrm{Y}_{\mathrm{aa}}\right.\right.$ $\left.\left.\times Z_{\mathrm{ab}}\right)\right]$.

If $\mathrm{A}_{\mathrm{ab}}=0$, both cultures are equally competitive; if $A_{a b}>0$, the ability of culture a (forage cactus) exceeds $\mathrm{b}$ (sorghum) in the intercropping, thus, the forage cactus is the dominant culture (Oseni \& Aliyu, 2010). The same reasoning applies to $\mathrm{A}_{\mathrm{ba}}$.

LAGY was determined by the following equation: $\mathrm{LAGY}=\left[\operatorname{UET}_{\mathrm{a}} \times\left(100 / \mathrm{Z}_{\mathrm{ab}}\right)-1\right]+\left[\mathrm{UET}_{\mathrm{b}} \times\left(100 / \mathrm{Z}_{\mathrm{ba}}\right)-1\right]$.

If $\mathrm{LAGY}_{\mathrm{ab}}>0$, there is an indication of the accumulated advantage of the intercropping in relation to the single system, if $\mathrm{LAGY}_{\mathrm{ab}}<0$, there is an indication of disadvantage of the intercropping. The actual loss or gain of yield includes LER on the basis of its calculation, as well as the space used in the field under the conditions of the intercropping and single $\operatorname{crop}\left(\mathrm{Z}_{\mathrm{ab}}\right.$ and $\left.\mathrm{Z}_{\mathrm{ba}}\right)$.

CR represents the number of times when one crop is more competitive than the other, and it is obtained from the index of aggressiveness: $\mathrm{CR}_{\mathrm{a}}=\left(\mathrm{LER}_{\mathrm{a}} / \mathrm{LER}_{\mathrm{b}}\right)$ $\times\left(\mathrm{Z}_{\mathrm{ba}} / \mathrm{Z}_{\mathrm{ab}}\right)$ and $\mathrm{CR}_{\mathrm{b}}=\left(\mathrm{LER}_{\mathrm{b}} / \mathrm{LER}_{\mathrm{a}}\right) \times\left(\mathrm{Z}_{\mathrm{ab}} / \mathrm{Z}_{\mathrm{ba}}\right)$.

If $\mathrm{CR}_{\mathrm{a}}<1$, a positive benefit occurs, and the crop can be grown in association; if $\mathrm{CR}_{\mathrm{a}}>1$, a negative effect of the crop occurs, showing a greater competitiveness, which does not indicate its cultivation in association. This interpretation is also valid for species b (Egbe et al., 2010).

Productivities on the fresh basis and on the dry basis, as well as dry mass content, were compared between water irrigation depths and planting systems. After that, the effect of these factors on the individual productivity of the intercropping cultures, in comparison to the single crop, was evaluated at different irrigation water depths. The indices of biological efficiency and competitive ability of the intercropping system were compared between the irrigation water depths. Data were subjected to normality and homoscedasticity tests and, then, to the analysis of variance. When necessary, their means were compared by the Tukey's test, at $5 \%$ probability, and the quantitative data were subjected to the regression analysis.

\section{Results and Discussion}

The increase of the water depths enhanced the agronomic performance of the forage cactus-sorghum intercropping, mainly because of the benefits to sorghum crop, despite the greater reduction of sorghum yield than the intercropped forage cactus (Table 2).

The individual yield on fresh basis (FM) and on dry basis (DM), and the dry matter content (DMC) of forage cactus and sorghum were not affected by the interaction of the irrigation water depths and planting systems.

The increase of irrigation water availability reduced the forage cactus DMC (Figure 1), but it did not significantly affect the accumulation of FM and DM, that is, $355 \mathrm{~mm}$ were sufficient for the productive performance of the crop, which confirms its high efficiency in the water use (Scalisi et al., 2016). FloresHernández et al. (2004) and Queiroz et al. (2015) used water depths higher than 760 and $976 \mathrm{~mm}$ per year, and they did not find any effects on the forage cactus yield. However, in the present study, the increment of the water depths increased the FM and individual DM of sorghum and the intercropped forage cactussorghum system (Figures 2 and 3). Similar trend was reported by Guimarães et al. (2016) and Silva et al. (2014) for sorghum in single crop system; and by Oseni \& Aliyu (2010) and Wang et al. (2015) for sorghum

Table 2. Individual productivity on fresh basis (FM) and on dry basis (DM), and dry matter content (DMC) of 'Orelha de Elefante Mexicana' forage cactus (Opuntia stricta) and 'SF-15' sorghum (Sorghum bicolor), in single crop system and intercropping system (forage cactus-sorghum), under different irrigation water depths (saline water irrigation at $355,563,725,867$, and $1,012 \mathrm{~mm}$ per year, plus rainfall), in the Brazilian Semiarid Region ${ }^{(1)}$.

\begin{tabular}{lcccc}
\hline Crop & $\begin{array}{c}\text { Planting } \\
\text { system }\end{array}$ & $\begin{array}{c}\text { FM } \\
\left(\mathrm{kg} \mathrm{ha}^{-1}\right)\end{array}$ & $\begin{array}{c}\text { DM } \\
\left(\mathrm{kg} \mathrm{ha}^{-1}\right)\end{array}$ & DMC \\
\hline Forage cactus & $\begin{array}{c}\text { Single crop } \\
\text { Intercropping }\end{array}$ & $\begin{array}{c}44,009 \mathrm{aB} \\
25,410 \mathrm{~b}\end{array}$ & $\begin{array}{c}4,627 \mathrm{aB} \\
3,573 \mathrm{a}\end{array}$ & $\begin{array}{c}0.11 \mathrm{bC} \\
0.14 \mathrm{a}\end{array}$ \\
\hline Sorghum & Single crop & $62,013 \mathrm{aA}$ & $14,073 \mathrm{aA}$ & $0.22 \mathrm{aA}$ \\
& Intercropping & $34,665 \mathrm{~b}$ & $8,557 \mathrm{~b}$ & $0.21 \mathrm{a}$ \\
\hline $\begin{array}{l}\text { Forage cactus- } \\
\text { sorghum }\end{array}$ & Single crop & $60,075 \mathrm{~A}$ & $12,130 \mathrm{~A}$ & $0.19 \mathrm{~B}$ \\
\hline
\end{tabular}

(1) Means followed by equal lowercase letters, in the same crop, and uppercase letters, between planting systems, do not differ by the Tukey's test, at $5 \%$ of probability. 
and cowpea intercropping and other associations. The individual DMC of sorghum and the intercropping, similar to that of the forage cactus, reduced as water depth was increased.

Based on these results, it can be inferred that the use of irrigation, during the first year of the forage cactus's cycle, promoted more accumulation of water in the cladodes than the increase of dry matter. Therefore, in years with low rainfall, or in locations with limited-water source, the impact on dry matter production may not be evidenced. According to Scalisi et al. (2016) the regulated irrigation reduction may not affect the dry matter accumulation of forage cactus, although under strong water stress, the growth rate of cladodes, relative water content, malic acid accumulation, and stomatal conductance are very low.

Moreover, the present study showed that the salinity of irrigation water, which reached $2.5 \mathrm{dS} \mathrm{m}^{-1}$, did not affect crop yield. Freire (2012) reported the tolerance of 'Orelha de Elefante Mexicana', in comparison to other cultivars, when irrigated with saline water at $3.6 \mathrm{dS} \mathrm{m}^{-1}$ every 14 days. Guimarães et al. (2016) also verified the tolerance of irrigated sorghum with saline effluent from fish farming.

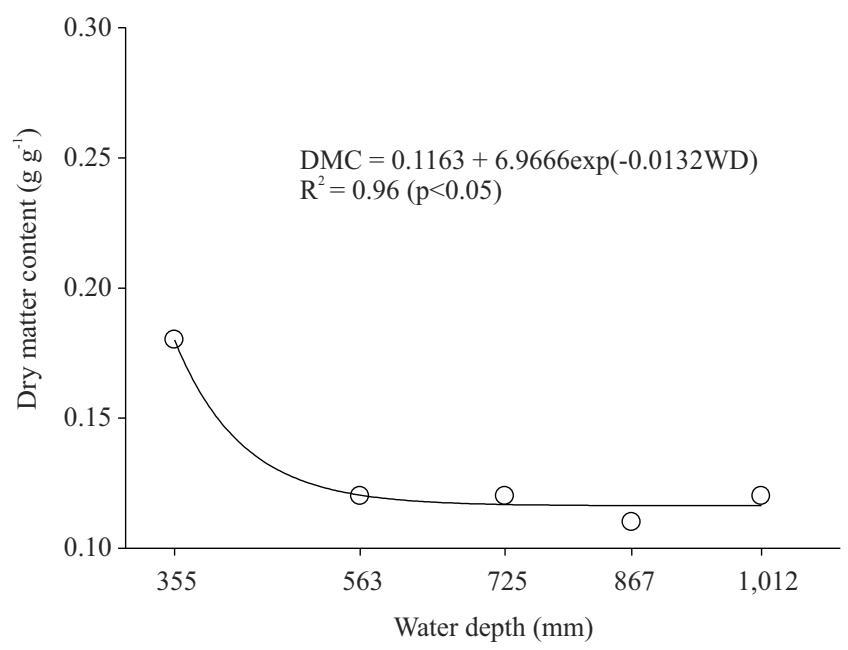

Figure 1. Effect of irrigation water depths (WD, saline water at $355,563,725,867$, and $1,012 \mathrm{~mm}$ per year, plus rainfall) on the dry matter content of 'Orelha de Elefante Mexicana' forage cactus (Opuntia stricta) in the single crop system and in the intercropping system with 'SF-15' sorghum (Sorghum bicolor), in the Brazilian Semiarid Region.
As to the planting system, intercropping affected neither forage cactus DM nor sorghum DMC, but reduced forage cactus FM and individual DMC, and sorghum FM and DM (Table 2). Nonetheless, the

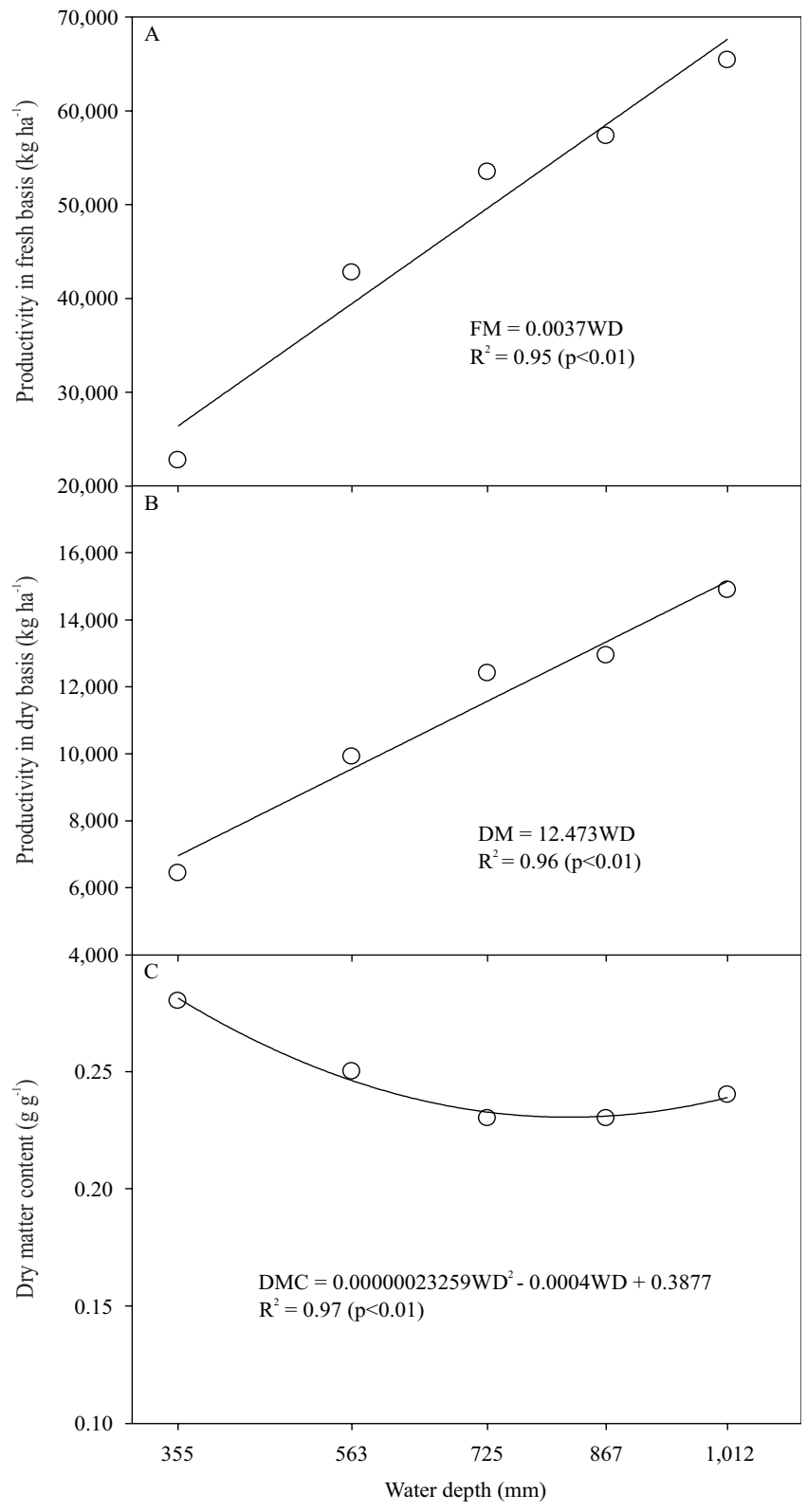

Figure 2. Effect of irrigation water depths (WD, saline water at $355,563,725,867$, and $1,012 \mathrm{~mm}$ per year, plus rainfall) on the productivity: $\mathrm{A}$, on fresh basis (FM); $\mathrm{B}$, on dry basis (DM); and C, dry matter content (DMC) of 'SF-15' sorghum (Sorghum bicolor), in single crop system or intercropped with 'Orelha de Elefante Mexicana' forage cactus (Opuntia stricta) in the Brazilian Semiarid Region. 
intercropping and the sorghum single crop were the systems that showed the best agronomic performances for FM and DM, despite their reduced DMC in the intercropping. The productive benefits of the intercropping in comparison to their monocultures were also highlighted by Souza et al. (2011), Silva et

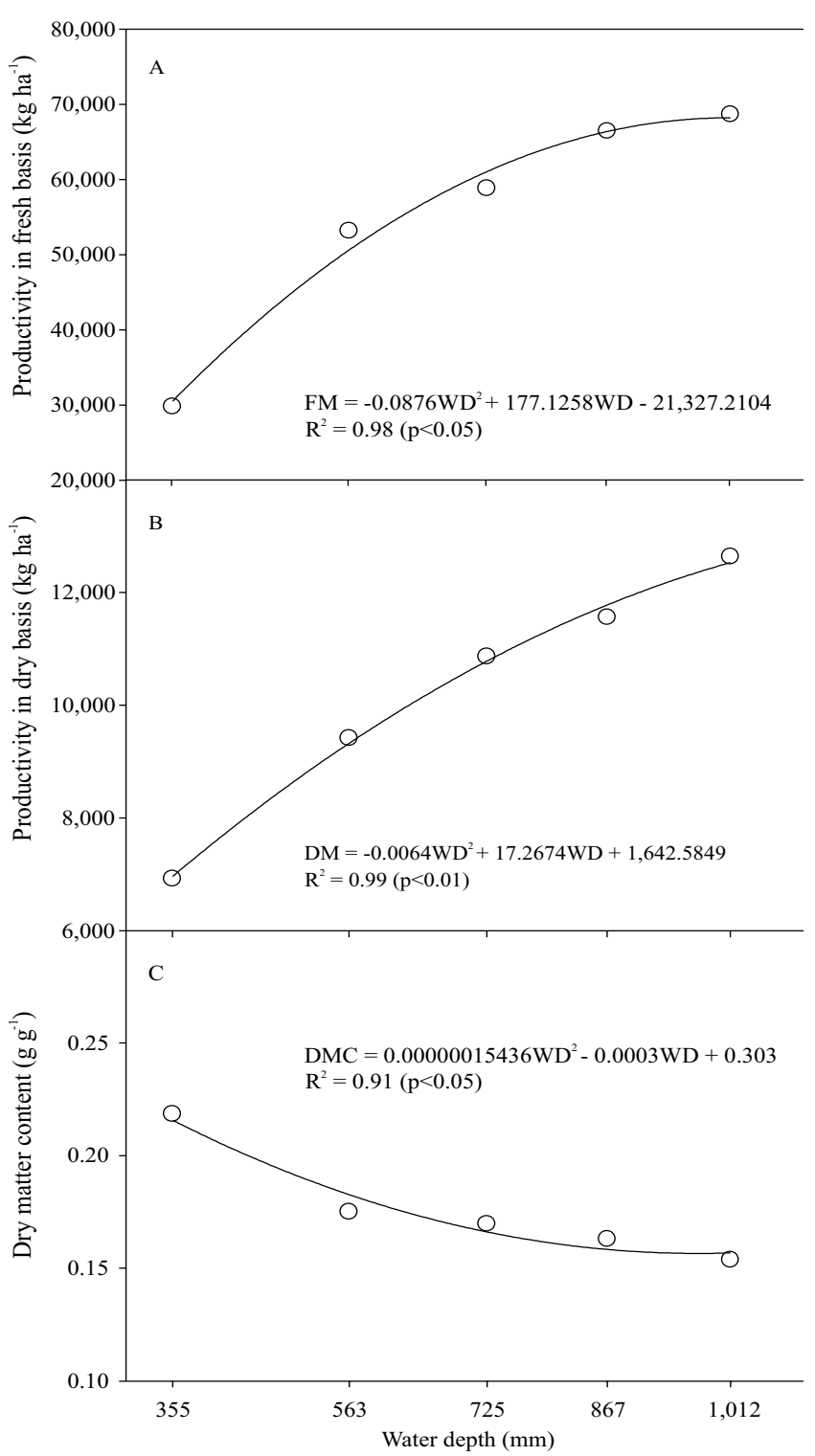

Figure 3. Effect of irrigation water depths (WD, saline water at $355,563,725,867$, and $1,012 \mathrm{~mm}$ per year, plus rainfall) on productivity: $\mathrm{A}$, on fresh basis (FM); $\mathrm{B}$, on dry basis (DM); and C, content of dry matter (DMC) of 'Orelha de Elefante Mexicana' forage cactus (Opuntia stricta)'SF-15' sorghum (Sorghum bicolor) intercropping, in the Brazilian Semiarid Region. al. (2013) and Silva et al. (2015). This advantage of intercropping is associated with the biological ability of the plants to adapt to a new growing environment, and their ability to compete for natural resources, especially water, light, and nutrients (Sadeghpour et al., 2013).

Irrigation water depths did not affect the biological efficiency and competitive ability of the forage cactussorghum intercropping; this means that the productive performance of the intercropping, in comparison to their monocultures, is inherent in the association of crops and independent of water availability. In the examined studies, this type of result is not mentioned, and in most of them, the intercropping systems were tested in dry conditions or without differentiation of irrigation water depths (Miriti et al., 2012; Sadeghpour et al., 2013; Silva et al., 2013).

In the biological evaluation of the forage cactussorghum intercropping, no effect of the water depth was observed. By the partial land efficiency use, it was verified that the sorghum yield loss $(\mathrm{LERb}=0.65)$ was higher than that of forage cactus (LERa $=0.87)$ (Table 3 ). The overall yield of the intercropping was $51 \%$ $(\mathrm{LER}=1.51)$, which makes it necessary an increase of 0.51 ha of the single system to match the productivity of the crop association. Land efficiency use greater than 1.0 is an indication that the intercropping is more efficient in land use than the single systems of its crops, and that there is biological sustainability of the intercropping (Kumar \& Thakur, 2006; Wortman et al., 2012). Silva et al. (2013) analyzed the performance of cotton crop and oleaginous crops intercropped with forage cactus, and found LER values between 2.58 and 2.99. The area-time equivalent ratio was 1.30 , which indicates that the forage cactus-sorghum intercropping has a biological advantage of $30 \%$ in land use and in time.

Land equivalent coefficient (LEC) was 0.58 (LEC > $0.25)$, which is an indication of the superiority of the intercropping in relation to its monocultures (Joseph \& Balan, 2008; Egbe et al., 2010). With the system productivity index (SPI), the sorghum productivity was converted to forage cactus yield, with which the intercropping was shown to have reached 6,279.02 $\mathrm{kg} \mathrm{DM} \mathrm{ha}{ }^{-1}$ and promoted stability in the production, as its SPI was higher than that of forage cactus in single crop $\left(4,626.98 \mathrm{~kg} \mathrm{DM} \mathrm{ha}^{-1}\right)$ 
The competitive ability of the intercropping, similarly to biological efficiency, was not affected by the irrigation water depths. The coefficient of partial relative density of forage cactus $\left(\mathrm{K}_{\mathrm{a}}=34.80\right)$ was higher than that of sorghum $\left(\mathrm{K}_{\mathrm{b}}=0.45\right)$, which is indicative of a strong interspecific competition, so that sorghum is dominated by forage cactus in the intercropping (Table 3). In turn, the product of the partial values of forage cactus and sorghum $(\mathrm{K}=12.33)$ was higher than 1.0 , which characterizes an optimal intercropping compatibility between these crops. The competitiveness ratio of the forage cactus $\left(\mathrm{CR}_{\mathrm{a}}\right)$ showed a higher magnitude (16.27) than that of sorghum $\left(\mathrm{CR}_{\mathrm{b}}=0.09\right)$; therefore, forage cactus had 16.27 times more competition capacity than sorghum. This trend was confirmed by the forage cactus aggressiveness index over sorghum $\left(\mathrm{A}_{\mathrm{ab}}\right)$, which was positive (9.60), characterizing forage cactus as the dominant culture of the system. The association

Table 3. Mean values of biological efficiency and competitiveness ability of forage cactus (Opuntia stricta)sorghum (Sorghum bicolor) intercropping under five irrigation water depths (saline water irrigation at 355, $563,725,867$, and $1,012 \mathrm{~mm}$ per year, plus rainfall), in the Brazilian Semiarid Region ${ }^{(1)}$.

\begin{tabular}{lc}
\hline Variable & Value \\
\hline Biological efficiency indicators & \\
LER $_{\mathrm{a}}$, forage cactus partial land efficient use & 0.87 \\
LER $_{\mathrm{b}}$, sorghum partial land efficient use & 0.65 \\
LER, total land efficient use & 1.51 \\
ATER, area-time equivalent ratio & 1.30 \\
LEC, land equivalent coefficient & 0.58 \\
SPI, system productivity index (kg ha ${ }^{-1}$ dry matter) & $6,279.02$ \\
\hline Competitive ability indicators & \\
K, coefficient of relative density & 12.33 \\
$\mathrm{~K}_{\mathrm{ab}}, \mathrm{K}$ of forage cactus over sorghum & 34.80 \\
$\mathrm{~K}_{\mathrm{ba}}, \mathrm{K}$ of sorghum over forage cactus & 0.45 \\
$\mathrm{CR}_{\mathrm{a}}$, forage cactus competitiveness ratio & 16.27 \\
$\mathrm{CR}_{\mathrm{b}}$, sorghum competitiveness ratio & 0.09 \\
$\mathrm{~A}_{\mathrm{ab}}$, forage cactus aggressiveness over sorghum & 9.60 \\
$\mathrm{~A}_{\mathrm{ba}}$, sorghum aggressiveness over forage cactus & -9.60 \\
LAGY $_{\mathrm{a}}$, loss or actual gain of yield of forage cactus & $1,029.45$ \\
LAGY $_{\mathrm{b}}$, loss or actual gain of yield of sorghum & 69.67 \\
LAGY, loss or gain of yield & $1,099,12$ \\
\hline
\end{tabular}

of these crops promoted yield gains (forage cactus, $\mathrm{LAGY}_{\mathrm{a}}=1,029.45 ;$ sorghum, $\mathrm{LAGY}_{\mathrm{b}}=69.67$ ) and, consequently, productive advantage over monocultures.

\section{Conclusions}

1. Sorghum (Sorghum bicolor) in single crop and the forage cactus (Opuntia stricta)-sorghum intercropping are the systems that most respond in productivity to the increase of the irrigation water depths with saline water.

2. The irrigation water depth of $355 \mathrm{~mm}$ is sufficient to guarantee the productivity of fresh and dry matter of forage cactus in the first year of the cycle.

3 . The forage cactus-sorghum intercropping shows a biological advantage and competitive capacity in relation to its monocultures, with greater productive benefit, land use efficiency, excellent association between crops, and domination of forage cactus over sorghum.

\section{Acknowledgments}

To Conselho Nacional de Desenvolvimento Científico e Tecnológico (CNPq), for financial support (process No. 475279/2010-7); and to Coordenação de Aperfeiçoamento de Pessoal de Nível Superior (Capes), for scholarship granted.

\section{References}

ALLEN, R.G.; PEREIRA, L.S.; RAES, D.; SMITH, M. Crop evapotranspiration: guidelines for computing crop water requirements. Rome: FAO, 1998. 300p. (FAO. Irrigation and Drainage Paper, n.56).

ATIS, I.; KOKTEN, K.; HATIPOGLU, R.; YILMAZ, S.; ATAK, M.; CAN, E. Plant density and mixture ratio effects on the competition between common vetch and wheat. Australian Journal of Crop Science, v.6, p.498-505, 2012.

COSTA, D.S. da; BARBOSA, R.M.; SÁ, M.E. de. Sistemas de produção e cultivares de feijoeiro em consórcio com milho. Scientia Agraria, v.11, p.425-430, 2010. DOI: 10.5380/rsa. v11i6.20387.

EGBE, O.M.; ALIBO, S.E.; NWUEZE, I. Evaluation of some extra-early and early maturing cowpea varieties for intercropping with maize in Southern Guinea Savana of Nigeria. Agriculture and Biology Journal of North America, v.1, p.845-858, 2010. DOI: 10.5251/abjna.2010.1.5.845.858.

FARIAS, I.; LIRA, M. de A.; SANTOS, D.C. dos; TAVARES FILHO, J.J.; SANTOS, M.V.F. dos; FERNANDES, A. de P.M.; 
SANTOS, V.F. dos. Manejo de colheita e espaçamento da palma forrageira, em consórcio com sorgo granífero, no Agreste de Pernambuco. Pesquisa Agropecuária Brasileira, v.35, p.341347, 2000. DOI: 10.1590/S0100-204X2000000200013.

FLORES-HERNÁNDEZ， A.; ORONA-CASTILLO, I.; MURILLO-AMADOR， B.; GARCIA-HERNANDEZ， J.L.; TROYO-DIEGUEZ, E. Yield and physiological traits of prickly pear cactus 'nopal' (Opuntia spp.) cultivars under drip irrigation. Agricultural Water Management, v.70, p.97-107, 2004. DOI: 10.1016/j.agwat.2004.06.002.

FREIRE, J. de L. Avaliação de clones de palma forrageira (Opuntia e Nopalea) sob irrigação e salinidade. 2012. 85p. Tese (Doutorado) - Universidade Federal Rural de Pernambuco, Recife.

GALVÃO JÚNIOR, J.G.B.; SILVA, J.B.A. da; MORAIS, J.H.G.; LIMA, R.N. de. Palma forrageira na alimentação de ruminantes: cultivo e utilização. Acta Veterinaria Brasilica, v.8, p.78-85, 2014. DOI: 10.21708/avb.2014.8.2.3490.

GUIMARÃES, M.J.M.; SIMÕES, W.L.; TABOSA, J.N.; SANTOS, J.E. dos; WILLADINO, L. Cultivation of forage sorghum varieties irrigated with saline effluent from fishfarming under semiarid conditions. Revista Brasileira de Engenharia Agrícola e Ambiental, v.20, p.461-465, 2016. DOI: 10.1590/1807-1929/agriambi.v20n5p461-465.

JOSEPH, S.; BALAN, B. Biological efficiency of ash ground based intercropping systems. Indian Journal of Agricultural Research, v.42, p.86-91, 2008.

KIREMIT, M.S.; ARSLAN, H. Effects of irrigation water salinity on drainage water salinity, evapotranspiration and other leek (Allium porrum L.) plant parameters. Scientia Horticulturae, v.201, p.211-217, 2016. DOI: 10.1016/j.scienta.2016.02.001.

KUMAR, A.; THAKUR, K.S. Effect of Brassica spp. and their sowing proportions on productivity, competition and economics of wheat (Triticum aestivum) + Brassica mixed cropping system under rainfed conditions of Himachal Pradesh. Indian Journal of Agronomy, v.51, p.259-262, 2006.

MIRITI, J.M.; KIRONCHI, G.; ESILABA, A.O.; HENG, L.K.; GACHENE, C.K.K.; MWANGI, D.M. Yield and water use efficiencies of maize and cowpea as affected by tillage and cropping systems in semi-arid Eastern Kenya. Agricultural Water Management, v.115, p.148-155, 2012. DOI: 10.1016/j. agwat.2012.09.002.

OLIVEIRA, F.T. de; SOUTO, J.S.; SILVA, R.P. da; ANDRADE FILHO, F.C. de; PEREIRA JUNIOR, E.B. Palma forrageira: adaptação e importância para os ecossistemas áridos e semiáridos. Revista Verde, v.5, p.27-37, 2010.

OSENI, T.O.; ALIYU, I.G. Effect of row arrangements on sorghum-cowpea intercrops in the semi arid savannah of Nigeria. International Journal of Agriculture and Biology, v.12, p.137-140, 2010.

QUEIROZ, M.G. de; SILVA, T.G.F. da; ZOLNIER, S.; SILVA, S.M.S. e; LIMA, L.R.; ALVES, J. de O. Características morfofisiológicas e produtividade da palma forrageira em diferentes lâminas de irrigação. Revista Brasileira de
Engenharia Agrícola e Ambiental, v.19, p.931-938, 2015. DOI: 10.1590/1807-1929/agriambi.v19n10p931-938.

SADEGHPOUR, A.; JAHANZAD, E.; ESMAEILI, A.; HOSSEINI, M.B.; HASHEMI, M. Forage yield, quality and economic benefit of intercropped barley and annual medic in semi-arid conditions: additive series. Field Crops Research, v.148, p.43-48, 2013. DOI: 10.1016/j.fcr.2013.03.021.

SANTOS, H.G. dos; JACOMINE, P.K.T.; ANJOS, L.H.C. dos; OLIVEIRA, V.A. de; LUMBRERAS, J.F.; COELHO, M.R.; ALMEIDA, J.A. de; CUNHA, T.J.F.; OLIVEIRA, J.B. de. Sistema brasileiro de classificação de solos. 3.ed. rev. e ampl. Brasília: Embrapa, 2013. 353p.

SCALISI, A.; MORANDI, B.; INGLESE, P.; LO BIANCO, R. Cladode growth dynamics in Opuntia ficus-indica under drought. Environmental and Experimental Botany, v.122, p.158-167, 2016. DOI: 10.1016/j.envexpbot.2015.10.003.

SILVA, D.V.; PEREIRA, G.A.M.; FREITAS, M.A.M. de; SILVA, A.A. da; SEDIYAMA, T.; SILVA, G.S.; FERREIRA, L.R.; CECON, P.R. Produtividade e teor de nutrientes do milho em consórcio com braquiária. Ciência Rural, v.45, p.1394-1400, 2015. DOI: $10.1590 / 0103-8478$ cr20140760.

SILVA, G. dos S.; OLIVEIRA, R.A. de; QUEIROZ, N.L.; SILVA, M.N.B. da; SOUSA, M.F. de; SILVA, S.A. da. Desempenho agronômico de algodão orgânico e oleaginosas consorciados com palma forrageira. Revista Brasileira Engenharia Agrícola Ambiental, v.17, p.975-981, 2013. DOI: 10.1590/ S1415-43662013000900010.

SILVA, J.L. de A.; MEDEIROS, J.F. de; ALVES, S.S.V.; OLIVEIRA, F. de A. de; SILVA JUNIOR, M.J. da; NASCIMENTO, I.B. do. Uso de águas salinas como alternativa na irrigação e produção de forragem no Semiárido Nordestino. Revista Brasileira de Engenharia Agrícola e Ambiental, v.18, p.S66-S72, 2014. Suplemento. DOI: 10.1590/1807-1929/ agriambi.v18nsupps66-s72.

SOUZA, L.S.B. de; MOURA, M.S.B. de; SEDIYAMA, G.C.; SILVA, T.G.F. da. Eficiência do uso da água das culturas do milho e do feijão-caupi sob sistemas de plantio exclusivo e consorciado no Semiárido brasileiro. Bragantia, v.70, p.715-721, 2011. DOI: $10.1590 / \mathrm{S} 0006-87052011000300030$.

THIERFELDER, C.; CHEESMAN, S.; RUSINAMHODZI, L. A comparative analysis of conservation agriculture systems: benefits and challenges of rotations and intercropping in Zimbabwe. Field Crops Research, v.137, p.237-250, 2012. DOI: 10.1016/j.fcr.2012.08.017.

WANG, Z.; ZHAO, X.; WU, P.; CHEN, X. Effects of water limitation on yield advantage and water use in wheat (Triticum aestivum L.)/maize (Zea mays L.) strip intercropping. European Journal of Agronomy, v.71, p.149-159, 2015. DOI: 10.1016/j. eja.2015.09.007.

WORTMAN, S.E.; FRANCIS, C.A.; LINDQUIST, J.L. Cover crop mixtures for the western Corn Belt: opportunities for increased productivity and stability. Agronomy Journal, v.104, p.699-705, 2012. DOI: 10.2134/agronj2011.0422

YILMAZ, S.; ÖZEL, A.; ATAK, M.; ERAYMAN, M. Effects 
of seeding rates on competition indices of barley and vetch intercropping systems in the Eastern Mediterranean. Turkish
Journal of Agriculture and Forestry, v.39, p.135-143, 2015. DOI: $10.3906 / \operatorname{tar}-1406-155$.

Received on June 10, 2016 and accepted on November 8, 2016 